\title{
Canine lacrimal and third eyelid superficial glands' macroscopic and morphometric characteristics
}

\author{
Aspectos macroscópicos e morfométricos das glândulas lacrimal e superficial da \\ terceira pálpebra de cães (Canis familiares; LINNAEUS, 1758)
}

\author{
Vânia Pais Cabral ${ }^{1}$ José Luiz Laus $^{2}$ Maria Lúcia Zaidan Dagli ${ }^{3} \quad$ Gener Tadeu Pereira $^{4}$ \\ Ivia Carmem Talieri ${ }^{1}$ Eduardo Raposo Monteiro ${ }^{5}$ Fabrício Villela Mamede ${ }^{1}$
}

\section{ABSTRACT}

The lacrimal and third eyelid superficial glands produce the aqueous component of the preocular tear film. In this research, morphologic and morphometric assessments of the parenchyma and stroma of both lacrimal glands of healthy adult mongrel dogs were performed. Both lacrimal and third eyelid glands of fourteen dogs were collected, summing fiftysix samples. The macroscopic and morphometric data were statistically analyzed, according to the glandular type (lacrimal and third eyelid superficial glands) and sexual dimorphism (male or female). The lacrimal glands were significantly larger and longer than the superficial glands of the third eyelid. Expressive morphometric differences of interlobular duct, lymphocytic infiltration, interlobular vessels and secretory parenchyma between the two glandular types were encountered. The lacrimal glands from the male subjects were significantly larger than those from female ones, as well as the superficial glands of the third eyelid were thicker. The higher lymphocyte infiltration and poorer secretor parenchyma in female dogs may be one of the reasons for the higher incidence of keratoconjunctiviti sicca (KCS) in such canine population.

Key words: lacrimal gland, third eyelid superficial lacrimal gland, macroscopy, morphometry, dogs.

\section{RESUMO}

As glândulas lacrimal e superficial da terceira pálpebra atuam produzindo o componente aquoso do filme lacrimal. Nesta pesquisa, estudaram-se aspectos morfológicos e morfométricos do parênquima e do estroma de ambas as glândulas em cães mestiços, hígidos, adultos (machos ou fêmeas). As glândulas lacrimal e superficial da terceira pálpebra de 14 cães foram colhidas, totalizando 56 amostras. Foram estudadas, à estatística, as variáveis macroscópicas e morfométricas, comparando-as quanto ao tipo glandular (lacrimal e superficial da terceira pálpebra) e quanto ao dimorfismo sexual (macho e fêmea). Às glândulas lacrimais foram significativamente maiores comparativamente as superficiais da terceira pálpebra. Foram evidenciados diferenças morfométricas expressivas quanto aos vasos e ductos interlobulares, ducto interlobular, infiltração linfocitária e parênquima secretório entre os dois tipos glandulares. As glândulas lacrimais dos machos foram significativamente maiores comparativamente às fêmeas, assim como as glândulas superficiais da terceira pálpebra apresentaram-se mais espessas. A maior infiltração linfocitária e a menor proporção de parênquima secretor nas fêmeas poderá ser uma das razões para uma maior incidência de ceratoconjuntivite seca (CCS) em fêmeas na população canina.

Palavras-chave: glândula lacrimal, glândula superficial da terceira pálpebra, macroscopia, morfometria, cães.

${ }^{1}$ Médico Veterinário e professor do Centro Universitário de Maringá, Doutorando do Programa de Pós-graduação em Cirurgia Veterinária da Faculdade de Ciências Agrárias e Veterinárias (FCAV), Universidade Estadual Paulista (UNESP) - Campus Jaboticabal. Via de Acesso Professor Paulo Donato Castelanne, Km 5, 14884-900, Jaboticabal, SP. Email: vaniacabral@ hotmail.com

${ }^{2}$ Médico Veterinário, Professor Titular, Departamento de Clínica e Cirurgia Veterinária, FCAV, UNESP, Campus Jaboticabal.

${ }^{3}$ Médico Veterinário, Professor Assistente, Departamento de Patologia Veterinária, Faculdade de Medicina Veterinária e Zootecnia (FMVZ), Universidade de São Paulo (USP).

${ }^{4}$ Professor Assistente do Departamento de Ciências Exatas, FCAV, UNESP, Campus Jaboticabal.

${ }^{5}$ Médico Veterinário, Mestrando do Programa de Pós-graduação em Anestesiologia, Faculdade de Medicina, UNESP, Campus Botucatu. 


\section{INTRODUCTION}

The lacrimal system is constituted by secretory and excretory portions, responsible for the production and the drainage of the tear film, respectively (WALDE et al., 1998). The lacrimal film is composed by three layers, differing in composition: an outer superficial layer consisting of lipids, produced by the meibomian glands; an intermediate one, composed of aqueous components, produced by the lacrimal and the third eyelid superficial glands; and an inner layer, consisting of mucin produced by goblet cells (DARTT, 2004).

Histologically, the lacrimal glands are constituted by secretory units, ducts and sustentation conjunctival tissue (DUGAN et al. 1992; CORMACK, 1996). The epithelial components (ducts and secretory units) compose the glandular parenchyma. Conjunctival tissue, including blood vessels and nerve fibers, constitutes the glandular stroma (CORMACK, 1996).

McCLELLAN et al. (2001) demonstrated that significant gender-related differences exist in lacrimal gland of rats, mice, guinea pigs, rabbits, and human beings. In all the species analyzed, acinar area in lacrimal glands of males was larger than that of females. Similarly, lacrimal glands from males rats produced significantly more IgA (HANN et al., 1988) and the levels of messenger RNA for specific proteins are approximately five times greater in lacrimal glands of males than those of females (SHAW et al., 1983).

The keratoconjunctivitis sicca (KCS) is a chronic inflammatory disease due to quantitative or qualitative abnormalities of the tear film, frequently reported in dogs. It has been reported that some breeds are prone to develop KCS, such as West highland white terriers and Cocker spaniels, with females being affected more frequently (BARROS et al., 1992).

Hypoplasia and agenesis of the lacrimal gland, chronic blepharoconjunctivitis, traumatic lesions causing glandular parasympathetic denervation, iatrogenic glandular exeresis, and protrusion and hyperplasia of the third eyelid superficial gland are some causes of KCS in dogs (ALMEIDA et al., 2004; FARIAS et al., 2002; MAITCHOUK et al., 2000). KCS can occur as an isolated phenomenon or secondary in association with various types of systemic autoimmune disorders (Sjögren's syndrome-like syndrome), azosulfapyridine toxicity and canine distemper (KASWAN et al., 1984).

KASWAN et al. (1984) considered some histologic characteristics to be normal of the lacrimal and third eyelid superficial glands: lobular arragement of short branched compound tubules; interlobular fat, connective tissue, and rare plasma cells and lymphocytes are normal features. Our research was conceived aiming at knowing aspects of the macroscopic and morphometric of the lacrimal and third eyelid superficial glands, as literature little clarifies such aspects. Therefore, we hope to contribuite with clinic and histopathologic studies as we quantify the structures of the stroma and the parenchyma of a helthy dog.

\section{MATERIAL AND METHODS}

Fourteen adult dogs mongrel (seven males and seven females) between 2 to 4 years old, median body weight 9 to 14 kilograms, from the canil at Centro Universitário de Maringá (PR -Brazil) shelter, were selected after physical, ophthalmic (fluorescein dye test, Schirmer tear test I, applanation tonometry) and hematological (complete blood cell count and serum biochemistry) examinations. The animals were vaccinated, neutered and kept in individual cages receiving water and concentrated food ad libitum. This study's protocols were performed according to the rules of the Association for Research in Vision and Ophthalmology (ARVO, 1985).

After hydric and food fasting for 12 hours, the animals received acepromazine ${ }^{\mathrm{a}}\left(0.1 \mathrm{mg} \mathrm{kg}^{-1}\right.$, iv $)$ as a preanesthetic. The anesthesia was induced by the intravenous injection of lidocaine ${ }^{\mathrm{b}}\left(3 \mathrm{mg} \mathrm{kg}^{-1}\right)$ and propofol $^{c}\left(2.5 \mathrm{mg} \mathrm{kg}^{-1}\right)$, followed by endotracheal intubation and inhalatory administration of halotane $\mathrm{d}^{\mathrm{d}}$ in closed circuit. Bilateral exeresis of the lacrimal glands was performed through a three-centimeter skin incision on the dorsolateral wall of the orbit.

After the periorbital incision, the lacrimal gland was ressected from underneath the orbital wall and the orbital fascia and retrobulbar fat were dissected from its surface. The periorbital fascia and subcutaneous tissue were sutured using 4-0poliglicolic acide and the skin with 6-0 mononylon ${ }^{\text {f }}$. The following procedures were the incision and dissection of the bulbar conjunctiva of the third eyelid and exposition of its superficial gland of the third eyelid. The glands (from both eyes) were removed after rupture of the connective tissue to the adjacent adnexa and its ressection from the cartilage of the third eyelid.

The 28 lacrimal glands and the 28 superficial glands of the third eyelid were submitted to morphometric and macroscopic studies. The macroscopic analysis was realized using a manual

Ciência Rural, v.35, n.2, mar-abr, 2005. 
pachymeter ${ }^{\mathrm{g}}$. Craniocaudal, lateral-lateral and dorsoventral axis were measured to check the length, width and thickness of the glands, respectively. After concluding the macroscopic analysis, the glands were fixed in $10 \%$ buffered formalin solution in dibasic anhydrous sodium phosphate and monobasic acid phosphate ( $\mathrm{pH} 7.0)$, dehydrated and blocked in paraffin, cut into five-micrometer thick and stained with Hematoxylin-Eosin (HE) and Masson Trichrome.

The light microscopy ${ }^{\mathrm{h}}$ studies were performed with $10 \mathrm{X}$ integrator objective lens and chamberi. The volumetric analysis of the structures was realized using Computer System Image Image Pro-plus . $^{\mathrm{j}}$ Each section was evaluated in 10 distinct fields, a reticulum of 70 points was employed as a standard for calibration, totalizing 700 points sample ${ }^{-1}$. The morphometric issues studied were the percentage of stromal and glandular parenchymal structures. The stromal structures studied were the conjunctival tissue, blood vessels, adipose cells, limphocytic infiltrate and myoepithelial cells. The parenchymal structures investigated were the acini, tubule and ducts of the lacrimal gland and superficial gland of the third eyelid.

The results were evaluated using the System for Elementary Statistical Analysis (SCHLOTZHAWER, 1999). The statistical relevance between the mean values was determined by the use of t-student test $(\mathrm{P}<0.05 ; \mathrm{P}<0.01)$, comparing the morphologic and morphometric data, according to the glandular type and sexual dimorphism.

\section{RESULTS}

Macroscospic analysis

The analysis of the data showed that the lacrimal glands were significantly larger than the superficial glands of the third eyelid $(\mathrm{P}<0.05)$ (Table 1$)$. The lacrimal glands from male animals were significantly larger than the ones from females $(\mathrm{P}<0.05)$ (Table 1). The superficial glands of the third eyelid were thicker in the males than in the females $(\mathrm{P}<0.01)$ (Table 1).

\section{Morphometric analysis}

Elements of secretory parenchyma (acini and tubule) and of the excretory parenchyma were quantified (intra and interlobular ducts) and compared between the groups (Figure 1B). The connective tissue (Figure 1A), blood vessels (Figure 1C), cellular infiltrate (Figure 1D), myoepithelial cells and adipose cells intra and interlobular (Figure 1E) were compared in order to analyze the stroma.

\section{Glandular type}

The secretory components of the lacrimal glands were statistically larger than the ones of the superficial glands of the third eyelid $(\mathrm{P}<0.01)$ (Table 2$)$. The average values of volumetric percentage of interlobular ducts (Figure 1B) in the lacrimal glands were lower $(\mathrm{P}<0.01)$ than in the superficial glands of the third eyelid (Table 2).

The interlobular blood vessels (Figure 1C) were encountered at a higher rate $(\mathrm{P}<0.05)$ in the third eyelid gland than in the lacrimal gland (Table 2). The average of cellular infiltrates (Figure 1D) was significantly more intense $(\mathrm{P}<0.01)$ in the superficial glands of the third eyelid (Table 2). Significant variations $(\mathrm{P}>0.05)$ in the other characteristics were not found.

\section{Sexual dimorphism}

The percentage of parenchyma was discretely higher than the stromal one in the lacrimal glands. The stroma-parenchyma volumetric percentage ratio was greater in the superficial glands of the third eyelid from female dogs. An inverse ratio was noticed for that gland in males dogs (Table 3).

There were significantly different average values $(\mathrm{P}<0.01)$ for the superficial glands of the third eyelid stroma (Figure 1A), between males and females.

Table 1 - Macrocospic analysis (length; width and the thickness) relatively the sexual dimorphism and the glandular type of mongrel dogs.

\begin{tabular}{|c|c|c|c|c|c|c|}
\hline \multirow{3}{*}{$\begin{array}{l}\text { Macroscopic } \\
\text { parameters }\end{array}$} & \multicolumn{2}{|c|}{ Glandular type } & \multicolumn{4}{|c|}{ Sexual dimorphism } \\
\hline & \multirow{2}{*}{ GL } & \multirow{2}{*}{ GST } & \multicolumn{2}{|c|}{ Female } & \multicolumn{2}{|c|}{ Male } \\
\hline & & & GL & GST & GL & GST \\
\hline Length & $1.70 * \pm 0.07$ & $1.27 \pm 0.03$ & $1.46 \pm 0.09$ & $1.25 \pm 0.05$ & $1.95 * \pm 0.08$ & $1.29 \pm 0.05$ \\
\hline Width & $0.76 \pm 0.03$ & $0.82 \pm 0.02$ & $0.74 \pm 0.03$ & $0.83 \pm 0.03$ & $0.79 \pm 0.05$ & $0.80 \pm 0.05$ \\
\hline Thickness & $0.41 * * \pm 0.02$ & $0.35 \pm 0.01$ & $0.38 \pm 0.02$ & $0.28 \pm 0.007$ & $0.43 \pm 0.02$ & $0.42 * * \pm 0.01$ \\
\hline
\end{tabular}

$\mathrm{GL}=$ Lacrimal gland; GST $=$ superficial gland of the third eyelid $(* \mathrm{P}<0.05 ; * * \mathrm{P}<0.01)$.

Ciência Rural, v.35, n.2, mar-abr, 2005. 

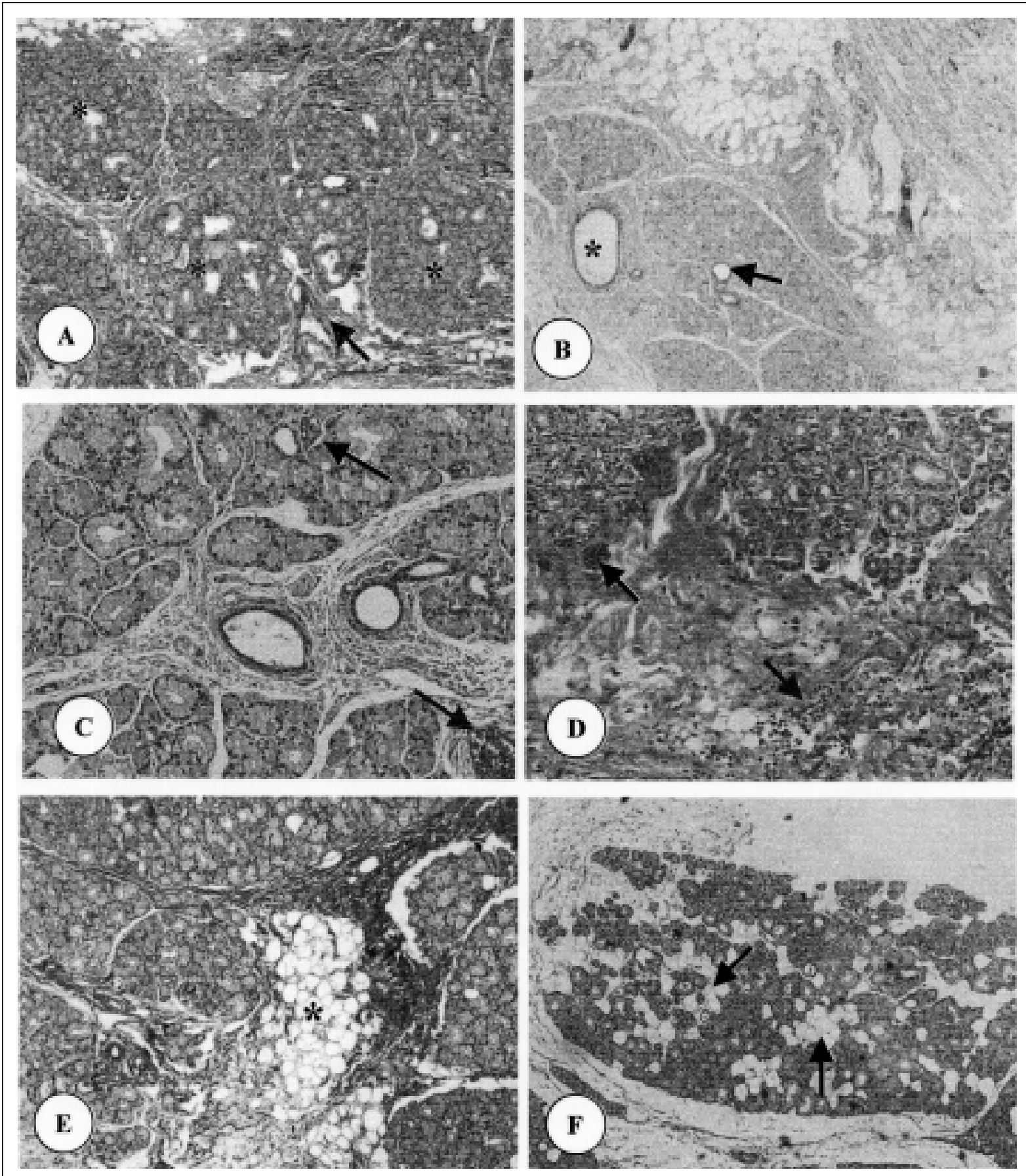

Figure 1 - Photomicrography of histological components of lacrimal (A,B, D gland and superficial gland of third eyelid's (C and E) of mongrel dogs. In A, lacrimal gland lobules (black asterisks) and interlobular connective tissue (black arrows) of the male dog (Hematoxylin-Eosin, original magnification X40). In B, Interlobular duct (black asterisk) and intralobular duct (black arrow) of the female dog (Hematoxylin-Eosin, original magnification X 40). In C, interlobular blood vessel (red arrows) and intralobular blood vessel (black arrows) of the female dog (Hematoxylin-Eosin, original magnification X100). In D, Infiltrate cellular in the interstitium (red arrows) and infiltrate cellular in surrounding the acini and tubule (black arrows) of the female dog (HematoxylinEosin, original magnification X100). In D, Interlobular adipose cells in the interstitium (black arrows) of the female dog (Masson Trichrome, original magnification X 40). In E, Intralobular adipose cells in the lobule gland (black arrows) of the female $\operatorname{dog}($ Hematoxylin-Eosin, original magnification X 40).

Ciência Rural, v.35, n.2, mar-abr, 2005. 
Table 2 - Volumetric percentage of histologic components, according to the glandular type of mongrel dogs.

\begin{tabular}{lcc}
\hline \multirow{2}{*}{\multicolumn{1}{c}{ Histologic components }} & \multicolumn{2}{c}{ Glandular type } \\
\cline { 2 - 3 } & GL & GST \\
\hline Parenchyma & $50.45 \pm 1.87$ & $48.16 \pm 2.03$ \\
Stroma & $49.45 \pm 2.43$ & $51.84 \pm 4.08$ \\
Acini and tubule & $48.39 * \pm 1.57$ & $43.32 \pm 1.40$ \\
Intralobular duct & $1.02 \pm 0.129$ & $1.41 \pm 0.16$ \\
Interlobular duct & $1.04 \pm 0.18$ & $3.43 * * \pm 0.47$ \\
Intralobular connective tissue & $9.83 \pm 0.62$ & $13.68 \pm 2.60$ \\
Interlobular connective tissue & $31.68 \pm 1.48$ & $29.57 \pm 2.34$ \\
Intralobular blood vessel & $0.43 \pm 0.07$ & $0.44 \pm 0.08$ \\
Interlobular blood vessel & $0.98 \pm 0.15$ & $1.74 * \pm 0.25$ \\
Myoepithelial cells & $0.38 \pm 0.95$ & $0.30 \pm 0.09$ \\
Cellular infiltrate & $3.04 \pm 0.34$ & $6.91 * * \pm 0.68$ \\
Intralobular adipose cells & $0.84 \pm 0.31 *$ & $0.33 \pm 0.11$ \\
Interlobular adipose cells & $0.86 \pm 0.37 *$ & $0.24 \pm 0.12$ \\
\hline
\end{tabular}

$\mathrm{GL}=$ Lacrimal gland; GST $=$ superficial gland of the third eyelid $(* \mathrm{P}<0.05 ; * * \mathrm{P}<0.01)$.

The average value of secretory parenchyma from male subjects was lower when compared to those from females. There were not evident differences in the lacrimal glands between male and female dogs (Table 3 ).

There was significant variation $(\mathrm{P}>0.05)$ of cellular infiltation (Figure 1D) in the lacrimal gland of females and males. The average percentage from females was higher, in a comparison to the one from male dogs. The amount of intralobular adipose cells (Figure 1E) in the superficial glands of the third eyelid and lacrimal gland varied significantly $(\mathrm{P}<0.05)$, between males and females. The other characteristics did not vary significantly $(\mathrm{P}>0.05)$ (Table 3 ).

\section{DISCUSSION}

The results here reported are similar to those previously reported by others. The canine lacrimal gland was found to be flat shaped, located between the zygomatic process and the dorsolateral region of the eyeball, underneath the orbital ligament. The canine superficial gland of the third eyelid is located at the base of the hyaline cartilage, close to the bulbar surface of the third eyelid (WALDE et al., 1998).

The secretory glandular terminals consisted of tubuloacinar units and acini arranged around the tubular segments, according to the results reported by CORMACK (1996). The interstitium was found to be constituted by some colagen fibers separating the glandular lobes, myoepitelial cells, plasma cells and limphocytes, as previously reported by others (DUGAN et al., 1992). MARCOS et al. (2002) concluded that the lacrimal and superficial of the third eyelid glands are closely similar, even though lipid inclusions are found in the eyelid gland's acini. However, in the present study, intra and interlobular adipose cells have been proven to exist in both glands.

Table 3 - Volumetric percentage of histologic components, according to sexual dimorphism of mongrel dogs.

\begin{tabular}{|c|c|c|c|c|}
\hline \multirow{3}{*}{ Histologic components } & \multicolumn{4}{|c|}{ Sexual dimorphism } \\
\hline & \multicolumn{2}{|c|}{ Female } & \multicolumn{2}{|c|}{ Male } \\
\hline & GL & GST & GL & GST \\
\hline Parenchyma & $50.17 \pm 5.00$ & $43.62 \pm 3.07$ & $50.74 \pm 4.47$ & $52.70 \pm 2.02$ \\
\hline Stroma & $49.83 \pm 2.29$ & $56.38 \pm 2.85$ & $49.26 \pm 3.59$ & $47.30 \pm 6.91$ \\
\hline Acini and tubule & $48.18 \pm 2.70$ & $39.30 \pm 2.0$ & $48.60 \pm 1.73$ & $48.60 \pm 1.73$ \\
\hline Intralobular duct & $1.20 \pm 1.16$ & $1.30 \pm 0.24$ & $0.83 \pm 0.97$ & $1.53 \pm 0.24$ \\
\hline Interlobular duct & $0.79 \pm 1.14$ & $3.02 \pm 0.83$ & $1.30 \pm 1.82$ & $3.84 \pm 0.48$ \\
\hline $\begin{array}{l}\text { Intralobular connective } \\
\text { tissue }\end{array}$ & $8.63 \pm 0.94$ & $10.50 \pm 0.69$ & $11.02 \pm 0.69$ & $16.87 \pm 5.11$ \\
\hline $\begin{array}{l}\text { Interlobular connective } \\
\text { tissue }\end{array}$ & $30.40 \pm 1.17$ & $32.40 \pm 2.1$ & $32.95 \pm 3.27$ & $26.74 \pm 1.8$ \\
\hline Intralobular blood vessel & $0.53 \pm 0.76$ & $0.49 \pm 0.11$ & $0.33 \pm 0.45$ & $0.39 \pm 0.12$ \\
\hline Interlobular blood vessel & $1.04 \pm 1.46$ & $2.17 \pm 0.37$ & $0.92 \pm 1.15$ & $1.31 \pm 0.33$ \\
\hline Myoepithelial cells & $0.37 \pm 0.05$ & $0.35 \pm 0.08$ & $0.38 \pm 0.04$ & $0.26 \pm 0.10$ \\
\hline Cellular infiltrate & $3.94 \pm 0.8 * *$ & $8.05 \pm 0.87$ & $2.14 \pm 0.5$ & $5.76 \pm 0.98$ \\
\hline Intralobular adipose cells & $0.39 \pm 0.15$ & $0.10 \pm 0.05$ & $1.30 \pm 0.59 *$ & $0.57 \pm 0.19 *$ \\
\hline Interlobular adipose cells & $1.27 \pm 0.61$ & $0.08 \pm 0.06$ & $0.45 \pm 0.45$ & $0.04 \pm 1.41$ \\
\hline
\end{tabular}

$\mathrm{GL}=$ Lacrimal gland; GST $=$ superficial gland of the third eyelid $(* \mathrm{P}<0.05 ; * * \mathrm{P}<0.01)$.

Ciência Rural, v.35, n.2, mar-abr, 2005. 
HELPER et al. (1974) reported that the production of the aqueous component of the lacrimal gland and superficial gland of the third eyelid could vary among individuals. It was proven that the volumetric percentage of secretory parenchyma (acini and tubule) of the lacrimal gland was larger than that of the superficial gland of the third eyelid.

In the histopathologic study the third eyelid superficial and lacrimal glands with KCS, finding was variable degrees of multifocal chronic adenitis characterized by acinar atrophy and replacement with increased numbers of plasma cells and lymphocytes within increased amounts of internacianr fibrous connective tissue stroma. Tubular structures were also dilated with neutrophils and cellular debris (KASWAN et al., 1984; CANAPP et al., 2001). According to the morphometric and quantitative analysis of excretory parenchyma (ducts), greater volumetric percentage of interlobular ducts were found in the lacrimal gland, after comparison to the superficial gland of the third eyelid.

Morphologic differences in relation to the sex have been reported by HANN et al. (1988) in some rodents, swines and human beings. In this study, the lacrimal glands from male mongrel dogs were found to be longer, comparatively to those from females. The male dogs' superficial gland of the third eyelid is thicker when compared to that from females.

In our research, height and length differences among the lacrimal glands were found to be significantly more intense than those of the superficial gland of the third eyelid. Reports about the quantitative differences of the aqueous component of the lacrimal film in dogs according to the sex, breed or phenotype are lacking (MOORE et al., 1987). In this study, however, the percentage of secretory parenchyma (acini and tubule) in females is comparatively lower than that in males. In the analyses here reported there were evidences of higher percentage of limphocytic infiltration in the lacrimal glands of females. The events can justify the higher rate of KCS in female dogs (BARROS et al., 1992).

\section{CONCLUSIONS}

Based on the results from this study, it is possible to admit that the lacrimal gland and superficial gland of the third eyelid from male dogs are longer, thicker and wider than the ones from females. Histologically, the lacrimal glands are bigger and present higher percentage of parenchyma than the superficial glands of the third eyelid of the same animal.
The superficial glands of the third eyelid presented greater percentage of limphocytic infiltration and larger number of interlobular ducts than the lacrimal glands in the same animal. The more intensive lymphocytic infiltration and a less abundant secretor parenchyma in female dogs, comparatively to the male ones, may evidence that the predominance of KCS in female dogs occurs for those reasons, among others.

\section{SOURCES OF ACQUISITION}

a.- Acepran: UNIVET S/A. Ind. Vet.

b.- Xylestesin : Cristália Prod. Quim. Farm LTDA.

c. Propovan: Cristália Prod. Quim. Farm LTDA

d.- Halotane: Cristália Prod. Quim. Farm. LTDA

e.- Dexon II: Sherwood Davis \& Medical Geck

f. - Nylon: Shalon Fios Manual Cirúrgicos LTDA

g - Pachymeter: Stainless Hardened

h. Nikon Eclipse E 800

i. - Nikon FDX-35 10

\section{ACKNOWLEDGMENTS}

The authors would like to thank Coordenação de Aperfeiçoamento de Pessoal de Nível Superior (CAPES) and Centro Universitário de Maringá (CESUMAR) for financial support.

\section{REFERENCES}

ALMEIDA,D.E. et al. Iatrogenic keratoconjunctivitis sicca in a dog. Ciência Rural, v.34, n,3, p.921-924, 2004.

ARVO, Association for Research in Vision and Ophthalmology. National Institutes of Health Publications. Sarasota- Flórida, 1985. n.85-23. 4p.

BARROS, P.S.M. et al. Aspectos clínicos da ceratoconjuntivite seca em cães. Estudo retrospectivo em 223 casos. ARS Veterinária, v.8, n.1, p.6-14, 1992.

CANAPP, S.O. et al. Xerostomia, xerophthalmia, and plasmacytic infiltrates of the salivary glands (Sjögren's-like syndrome) in a cat. Journal of American Veterinary Medical Association, v.218, n.1, p.59-65, 2001

CORMACK, D.H. Tecido epitelial. In: Fundamentos de histologia. Rio de Janeiro : Guanabara Koogan, 1996. Cap.3, p. $70-83$

DARTT, D.A. Control of mucin production by ocular surface epithelial cells. Experiment Eye Research v.78, n.2. p.173-85, 2004.

DUGAN, S.J. et al. Clinical and histologic evaluation of the prolapsed third eyelid gland in dogs. Journal of American Veterinary Medical Association, v.201, n.12, p.1861-1867, 1992.

Ciência Rural, v.35, n.2, mar-abr, 2005. 
FARIAS,V.M et al. Correção cirúrgica de prolapso de glândula de terceira pálpebra - relato de um caso. Ciência Animal, v.11, supl.2, p.162-164, 2002.

HANN, L. E. et al. Impact of aging and gender on the Ig-containing cell profile of the lacrimal gland. Acta Ophthalmologica, v.66, n.2, p.87-92, 1988.

HELPER, L.C. et al. Surgical induction of keratoconjunctivitis sicca in the dog. Journal of American Veterinary Medical Association, v.165, n.2, p.172-174, 1974

KASWAN. R. et al. Keratoconjunctivitis sicca: histopathologic study of nictitating membrane and lacrimal gland from 28 dogs American Journal of Veterinary Research, v.45, n.1, p.112 117,1984

MAITCHOUK, D.Y. et al. Tear production after unilateral removal of the main lacrimal gland in squirrel monkeys. Archives Ophthalmology, v.118, n.2, p.246-252, 2000

MARCOS, H.J.A. et al. Histology, histochemistry and fine structure of the lacrimal and nictitants gland in the south american armadillo Chaetophractus villosus (Xenarthra, mammalia). Experiment Eye Research, v.75, p.731-744, 2002

McCLELLAN, K.A. et al. Investigation of the role of prolactin in the development and function of the lacrimal and harderian glands using genetically modified mice. Investigative Ophthalmology Visual Science, v.42, n.1, p.23-30, 2001

MOORE, C.P. et al. Density and distribution of canine conjunctival goblet cells. Investigative Ophthalmology Visual Science, v.28, n.7, p.1925-1935, 1987

SCHLOTZHAWER, W. System for elementary statistical analysis institute inc., SAS/STAT. User's Guide. 5.ed. NC : SAS Institute, 1999. p.1290.

SHAW, P.H. et al. The gene family for major urinary proteins: expression in several tissue of the mouse. Cell , v.32, n.3, p755761, 1983.

WALDE, I. et al. Afecções do aparelho lacrimal. In: Atlas de clínica oftalmológica do cão e do gato. 2.ed. São Paulo : Manole, 1998. Cap.6, p.93-104. 